\title{
PROBLEM BASED LEARNING PADA MATA PELAJARAN FIQH DI MADRASAH IBTIDAIYAH
}

\author{
Maskur \\ Program Studi Pendidikan Agama Islam \\ Sekolah Tinggi Ilmu Agama Wali Sembilan Semarang \\ curma.gund@gmail.com
}

\begin{abstract}
Abstrak
Pembelajaran fiqh bertujuan memberikan pemahaman kepada peserta didik tentang berbagai macam syariat atau hukum Islam dan berbagai macam aturan hidup bagi manusia. Memberikan pemahaman terkait permasalahan tersebut tentunya bukan hal yang mudah terutama bagi siswa Madrasah Ibtidaiyah yang notabene harus senantiasa diberikan contoh konkrit maupun permasalahan yang dapat merangsang pemahaman siswa. Penelitian ini memiliki tujuan untuk melihat implementasi model pembelajaran Problem Based Learning pada mata pelajaran fiqh di Madrasah Ibtidaiyah. Penelitian ini merupakan penelitian kualitatif yang berlokasi di Madrasah Ibtidaiyah Miftahush Sibyan 01 Semarang. Sumber data penelitian diperoleh dari data primer dan data sekunder. Metode pengumpulan data dilakukan dengan wawancara, dokumentasi dan observasi, sedangkan metode analisis data menggunakan metode deskriptif analitis. Berdasarkan hasil penelitian yang telah peneliti lakukan dapat diperoleh simpulan bahwa implementasi pembelajaran fiqh dengan menggunakan model pembelajaran Problem Based Learning membantu pemahaman anak terkait materi fiqh menjadi lebih mudah, hal ini karena pembelajaran diarahkan untuk senantiasa memberikan permasalahan yang sederhana tetapi mampu memberikan pemahaman yang cukup konkrit kepada siswa.
\end{abstract}

Kata kunci: Problem Based Learning, pembelajaran, Fiqh

\begin{abstract}
Fiqh lesson aims to give understanding to the students about many syariat or Islamic roles and various life roles for human. Giving understanding about the problem is not easy thing especially for MI students who are always be given real example or problem which can stimulate students' understanding. This study aims to see implementation of learning model in Problem Based Learning on Fiqh Lesson for MI Miftahush Sibyan 01 Semarang. Source of the data were obtained from primer data and sekunder data. Data collection were done by interview, documentation and observation, while data analysis used analystical descriptive method. Based on the result of the study the conclusion that can be obtained that implementation of fiqh lesson with used PBL learning method is help student about fiqh material become easier, it is because the learning directed to always give simple problem but able to give concrete understanding to students.

Keywords: Problem Based Learning, Learning, Fiqh
\end{abstract}




\section{A. PENDAhUluAN}

Fiqh merupakan ilmu yang mempelajari bermacam-macam syariat atau hukum Islam dan berbagai macam aturan hidup bagi manusia baik yang bersifat individu maupun yang berbentuk masyarakat sosial. Mata pelajaran fiqh sebagai salah satu mata pelajaran di tingkat Madrasah Ibtidaiyah bertujuan memberikan pemahaman kepada siswa tentang berbagai syariat yang memberikan aturan yang berguna bagi kehidupan sehari-hari. Adapun hal-hal yang menjadi dasar dan pendorong bagi umat Islam untuk mempelajari ilmu fiqh adalah 1) untuk mencari kebiasaan paham dan pengertian dari agama Islam, 2) untuk mempelajari hukumhukum Islam yang berhubungan dengan kehidupan manusia, 3) kaum muslimin harus bertafaqquh artinya memperdalam pengetahuan tentang hukum-hukum agama baik dalam bidang aqidah dan akhlak maupun dalam bidang ibadat dan muamalat.

Pembelajaran fiqh di Madrasah Ibtidaiyah diharapkan tidak hanya sekedar memberikan penjelasan tentang kebiasaan paham maupun pengertian dari agama Islam ataupun mempelajari hukum-hukum Islam yang berhubungan dengan manusia, tetapi harus mampu memberikan pemahaman yang sesuai dengan perkembangan kehidupan manusia terutama dalam menghadapi berbagai permasalahan yang berkaitan dengan perkembangan hukum-hukum Islam yang harus sudah mulai dikenalkan kepada siswa usia Sekolah Dasar.

Fiqh pada dasarnya merupakan bagian dari pemahaman syari'ah yang tentunya sifatnya selalu mengalami perkembangan dari waktu ke waktu sesuai dengan kebutuhan manusia sesuai dengan zamannya. Dengan demikian pembelajaran fiqh harus disesuaikan dengan perkembangan dan pola pikir yang berkembang sesuai dengan kondisi dan kebutuhan manusia sesuai dengan kondisi dan realitas yang sesuai. Pembelajaran fiqh pada tingkat Madrasah Ibtidaiyah seyogyanya dapat memberikan gambaran secara teoritis dan secara praktis dengan melihat perkembangan hukum-hukum Islam sesuai dengan kebutuhan manusia. 
Pembelajaran fiqh di Madrasah Ibtidaiyah diperlukan metode maupun model pembelajaran yang lebih bervariasi dan sesuai dengan materi yang akan diajarkan oleh guru, terutama dalam mengenalkan berbagai permasalahan dalam pembelajaran Fiqh. Salah satu model pembelajaran yang dapat memberikan berbagai permasalahan terkait hukum-hukum Islam dan perkembangan permasalahan yang berkembang dalam kehidupan masyarakat adalah model pembelajaran Problem Based Learning. Model pembalajaran Problem Based Learning atau sering dikenal dengan pembelajaran berbasis masalah adalah model pengajaran yang bercirikan adanya permasalahan nyata sebagai konteks untuk para peserta didik belajar berfikir kritis dan keterampilan memecahkan masalah serta memperoleh pengetahuan.

Model pembelajaran Problem Based Learning akan memungkinkan siswa dalam mempelajari mata pelajaran fiqh yang dikaitkan dengan permasalahan nyata yang dihadapi dalam kehidupan sehari-hari, sehingga peserta didik dapat belajar untuk berfikir secara kritis dan memiliki keterampilan memecahkan masalah sesuai dengan kaidah hukum-hukum Islam yang berlaku tetapi dapat dikaitkan dengan konteks yang semestinya.

Berdasarkan hasil observasi awal dapat dilihat bahwa pembelajaran fiqh di lokasi penelitian lebih diutamakan dalam memberikan penjelasan dan pemahaman berkaitan dengan hukum-hukum Islam secara teoritis dalam proporsi yang jauh lebih besar tanpa dikaitkan dengan konteks permasalahan yang berkembang bagi kebutuhan siswa dalam mempelajari fiqh itu sendiri. Berdasarkan latar belakang tersebut, peneliti tertarik untuk meneliti implementasi model pembelajaran Problem Based Learning pada mata pelajaran Fiqh di Madrasah Ibtidaiyah.

\section{B. METODE PENELITIAN}

Penelitian ini merupakan penelitian kualitatif yang bermaksud untuk memahami fenomena tentang apa yang dialami oleh subjek penelitian misalnya perilaku, persepsi, motivasi, tindakan, dan lain-lain secara holistik, dan dengan 
cara deskripsi dalam bentuk kata-kata dan bahasa, pada suatu konteks khusus yang alamiah dan dengan memanfaatkan berbagai metode alamiah. ${ }^{1}$

Penelitian kualitatif merupakan penelitian yang menghasilkan data-data deskriptif, ucapan atau tulisan dan perilaku yang dapat diamati dari orang-orang (subyek) itu sendiri. Dengan menggunakan spesifikasi penelitian kualitatif maka akan dapat dilihat gambaran keadaan yang ada di Madrasah Ibtidaiyah Miftahush Sibyan 01 Semarang secara lebih objektif berkaitan dengan implementasi Problem Based Learning pada mata pelajaran Fiqh.

Sumber data yang digunakan dalam penelitian ini, terdiri dari sumber data primer dan sumber data sekunder. Data primer atau data tangan pertama adalah data yang diperoleh langsung dari subjek penelitian, diantaranya adalah dari Guru dan siswa. Adapun data sekunder diperoleh dari kepala sekolah yang merupakan unsur pendukung dalam implementasi model Problem Based Learning dalam mata pelajaran Fiqh.

Metode pengumpulan data dilakukan dengan wawancara, dokumentasi, dan observasi. Wawancara dilakukan kepada beberapa pihak yang terkait dengan implementasi model Problem Based Learning yakni kepada Guru, Siswa maupun Kepala Sekolah. Dokumentasi dilakukan untuk melihat dokumen-dokumen pendukung dalam implementasi model Problem Based Learning seperti perangkat pembelajaran yang digunakan guru, media pendukung yang digunakan guru. Adapun observasi dilakukan dengan melihat perencanaan, pelaksanaan dan evaluasi model Problem Based Learning. Metode analisis data dalam penelitian ini menggunakan metode deskriptif analitis, yang digunakan untuk mendeskripsikan hasil penelitian secara lebih jelas dan menggambarkan apa adanya tentang implementasi model Problem Based Learning di MI Miftahush Sibyan 01 Semarang.

\footnotetext{
${ }^{1}$ Lexy J. Moleong, Metode Penelitian Kualitatif, Bandung: Remaja Rosdakarya, 2005, hlm 6.
} 


\section{HASIL DAN PEMBAHASAN}

Pelajaran fiqh merupakan salah satu bagian mata pelajaran Pendidikan Agama Islam yang diarahkan untuk menyiapkan peserta didik untuk mengenal, memahami, menghayati dan mengamalkan hukum Islam yang kemudian menjadi dasar pandangan hidupnya melalui kegiatan bimbingan, pengajaran, latihan penggunaan, pengamalan dan pembiasaan.

Pembelajaran fiqih tersebut diberikan dengan tujuan utama untuk membekali peserta didik agar dapat: (1) mengetahui dan memahami pokok-pokok hukum Islam dalam mengatur ketentuan dan tata cara menjalankan hubungan manusia dengan Allah yang diatur dalam fiqih ibadah dan hubungan manusia dengan sesama yang diatur dalam fiqih muamalah. (2) Melaksanakan dan mengamalkan ketentuan hukum Islam dengan benar dalam melaksanakan ibadah kepada Allah dan ibadah sosial.

Tujuan Mata pelajaran Fiqih di Madrasah Ibtidaiyah adalah:

1. Agar siswa dapat mengetahui dan memahami pokok-pokok hukum Islam secara terperinci dan menyeluruh, baik berupa dalil naqli dan aqli, sebagai pedoman hidup bagi kehidupan pribadi dan sosialnya.

2. Agar siswa dapat melaksanakan dan mengamalkan ketentuan hukum Islam dengan benar, sehingga dapat menumbuhkan ketaatan menjalankan hukum Islam, disiplin dan tanggung jawab sosial yang tinggi dalam kehidupan pribadi maupun sosialnya.

Fungsi mata pelajaran Fiqih di Madrasah Ibtidaiyyah adalah:

1. Mendorong tumbuhnya kesadaran beribadah siswa kepada Allah SWT.

2. Menanamkan kebiasaan melaksanakan syarit Islam di kalangan siswa dengan ikhlas.

3. Mendorong tumbuhnya kesadaran siswa untuk mensyukuri nikmat Allah SWT dengan mengolah dan memanfaatkan alam untuk kesejahteraan hidup. 
4. Membentuk kebiasaan kedisiplinan dan rasa tanggung jawab sosial di madrasah dan di masyarakat.

5. Membentuk kebiasaan berbuat/berperilaku yang sesuai dengan peraturan yang berlaku di madrasah dan masyarakat. ${ }^{2}$

Mata pelajaran Fiqh di Madrasah Ibtidaiyah merupakan salah satu mata pelajaran Pendidikan Agama Islam yang mempelajari tentang Fiqh ibadah, terutama menyangkut pengenalan dan pemahaman tentang cara-cara pelaksanaan rukun Islam dan pembiasaannya dalam kehidupan sehari-hari, serta Fiqih muamalah yang menyangkut pengenalan dan pemahaman sederhana mengenai ketentuan tentang makanan dan minuman yang halal dan haram, khitan, kurban, serta tata cara pelaksanaan jual beli dan pinjam meminjam.

Pembelajaran merupakan bagian atau elemen yang memiliki peran yang sangat dominan untuk mewujudkan kualitas lulusan pendidikan. Hakikat pembelajaran yang utama adalah untuk mengasah atau melatih moral kepribadian manusia, oleh karena itulah proses pembelajaran dituntut untuk selalu menyesuaikan dinamika masyarakat. Dengan kata lain proses pembelajaran merupakan suatu proses yang di dalamnya dibutuhkan teknik dan model yang senantiasa sesuai dengan tuntunan zaman yang menjadi dinamika kehidupan masyarakat. Memberikan pemahaman kepada siswa dibutuhkan suatu pengenalan tentang teks dan konteks yang berkembang sesuai dengan perkembangan masyarakat yang tentunya perlu diikuti dengan perkembangan sebuah teori dalam pembelajaran.

Problem Based Learning merupakan model pembelajaran yang menyuguhkan berbagai situasi bermasalah yang autentik dan bermakna kepada siswa, yang dapat berfungsi sebagai batu loncatan untuk investigasi dan penyelidikan. ${ }^{3}$ Problem Based Learning pada dasarnya dirancang untuk membantu siswa mengembangkan keterampilan berpikir dan keterampilan menyelesaikan masalah, mempelajari peran-

\footnotetext{
${ }^{2}$ Keputusan Menteri Agama No 165 Tahun 2014, Pedoman Kurikulum madrasah 2013 Mata Pelajaran Pendidikan Agama Islam dan Bahasa Arab, Jakarta: Depag, hlm 35

${ }^{3}$ Richard I Arends, Learning to Teach: Belajar untuk Mengajar, Yogyakarta: Pustaka Pelajar, 2007, hlm 43 .
} 
peran orang dewasa dan menjadi pelajar yang mandiri. Model pembelajaran ini menyediakan sebuah alternatif yang menarik bagi guru yang menginginkan maju melebihi pendekatan-pendekatan yang lebih berpusat pada guru untuk menantang siswa dengan aspek pembelajaran aktif dalam model pembelajaran tersebut.

Problem Based Learning atau model pembelajaran berbasis masalah adalah sebuah model pembelajaran yang memfokuskan pada pelacakan akar masalah dan memecahkan masalah tersebut. ${ }^{4}$ Dengan memahami akar masalah yang berkembang sesuai dengan perkembangan manusia, siswa akan dapat berlatih untuk memberikan penyelesaian terhadap permasalahan yang terjadi tersebut. Hal ini tentunya sesuai dengan tujuan model Problem Based Learning yang diutamakan untuk penguasaan isi belajar dari disiplin heuristik dan pengembangan keterampilan pemecahan masalah. ${ }^{5}$

Problem Based Learning merupakan pengembangan kurikulum dan sistem pengajaran yang mengembangkan secara stimulan strategi pemecahan masalah dan dasar-dasar pengetahuan dan keterampilan dengan menempatkan para peserta didik dalam peran aktif sebagai pemecah permasalahan sehari-hari yang tidak terstruktur dengan baik. ${ }^{6}$

Memahami beberapa pengertian tentang model pembelajaran dapat diketahui bahwa model pembelajaran Problem Based Learning merupakan salah satu model pembelajaran yang berpusat pada peserta didik dengan cara menghadapkan para peserta didik tersebut dengan berbagai masalah yang dihadapi dalam kehidupannya. Dengan model pembelajaran ini, peserta didik dari sejak awal sudah dihadapkan kepada berbagai masalah kehidupan yang mungkin akan ditemuinya kelak setelah lulus dari bangku sekolah.

Model pembelajaran Problem Based Learning adalah cara penyajian bahan pelajaran dengan menjadikan masalah sebagai titik tolak pembahasan masalah untuk

\footnotetext{
${ }^{4}$ Nata Abbudin, Perspektif Islam tentang Strategi Pembelajaran, Jakarta: Kencana, 2011, hlm 243.

${ }^{5}$ Rusman, Model-Model Pembelajaran, Bandung: Rajawali Pers, 2010, hlm 238.

${ }^{6}$ Finkle and Torp dalam Aris Shoimin, Model Pembelajaran Inovatif dalam Kurikulum 2013, Yokyakarta: AR-ruz media, 2014, hlm 130.
} 
dianalisis dan disintesis dalam usaha mencari pemecahan atau jawabannya oleh siswa. Permasalahan dapat diajukan atau diberikan guru kepada siswa, dari siswa bersama guru, atau dari siswa sendiri, yang kemudian dijadikan pembahasan dan dicari pemecahannya sebagai kegiatan belajar siswa.

Fokus model pembelajaran berbasis masalah pada dasarnya terletak pada masalah yang dipilih sehingga siswa tidak saja mempelajari konsep-konsep yang berhubungan dengan masalah tetapi metode ilmiah untuk memecahkan masalah tersebut. ${ }^{7}$ Oleh sebab itu, siswa tidak saja harus memahami konsep yang relevan dengan masalah yang menjadi pusat perhatian tetapi juga memperoleh pengalaman belajar yang berhubungan dengan keterampilan menerapkan metode ilmiah dalam pemecahan masalah dan menumbuhkan pola berpikir kritis.

Pada dasarnya model pembelajaran berbasis masalah memiliki beberapa ciri utama, yakni: 1) Problem Based Learning merupakan rangkaian aktivitas pembelajaran, artinya dalam implementasi model pembelajaran ini ada sejumlah kegiatan yang harus dilakukan siswa. Model ini tidak mengharapkan siswa hanya sekadar mendengarkan, mencatat, kemudian menghafal materi pelajaran, akan tetapi melalui model pembelajaran Problem Based Learning siswa aktif berpikir, berkomunikasi, mencari dan mengolah data, dan akhirnya menyimpulkan. Kedua, aktivitas pembelajaran ditujukan untuk menyelesaikan masalah. Problem Based Learning menempatkan masalah sebagai kata kunci dalam pembelajaran. Artinya, tanpa masalah tidak mungkin ada proses pembelajaran. Ketiga, pemecahan masalah dilakukan dengan menggunakan pendekatan berpikir secara ilmiah. Berpikir dengan menggunakan metode ilmiah adalah proses berpikir deduktif dan induktif. Proses berpikir ini dilakukan secara sistematis dan empiris. ${ }^{8}$

Pelaksanaan model Problem Based Learning pada dasarnya harus melalui lima fase atau tahap yang perlu dilaksanakan, yaitu sebagai berikut:

\footnotetext{
${ }^{7}$ Ngalimun, Strategi dan Model pembelajaran, Yogyakarta: Aswaja Presindo, 2013, hlm 90.

${ }^{8}$ Wina Sanjaya, Strategi Pembelajaran Berorientasi Standar Proses Pendidikan. Jakarta: Prenada Media Group, 2010, hlm 214-215
} 
1. Proses orientasi peserta didik pada masalah. Pada tahap ini guru menjelaskan tujuan pembelajaran, menjelaskan logistik yang diperlukan, memotivasi peserta didik untuk terlibat dalam aktivitas pemecahan masalah, dan mengajukan masalah.

2. Mengorganisasi peserta didik. Pada tahap ini guru membagi peserta didik kedalam kelompok, membantu peserta didik mendefinisikan dan mengorganisasikan tugas belajar yang berhubungan dengan masalah.

3. Membimbing penyelidikan individu maupun kelompok. Pada tahap ini guru mendorong peserta didik untuk mengumpulkan informasi yang dibutuhkan, melaksanakan eksperimen dan penyelidikan untuk mendapatkan penjelasan dan pemecahan masalah.

4. Mengembangkan dan menyajikan hasil. Pada tahap ini guru membantu peserta didik dalam merencanakan dan menyiapkan laporan, dokumentasi, atau model, dan membantu mereka berbagi tugas dengan sesama temannya.

5. Menganalisis dan mengevaluasi proses dan hasil pemecahan masalah. Pada tahap ini guru membantu peserta didik untuk melakukan refleksi atau evaluasi terhadap proses dan hasil penyelidikan yang mereka lakukan. ${ }^{9}$

Implementasi Problem Based Learning pada mata pelajaran Fiqh yang dilakukan di MI Miftahush Sibyan 01 yang dilaksanakan pada kelas IV pada materi membiasakan penerapan nilai-nilai yang terkandung dalam salat Jum'at. Pembelajaran mendasarkan pada sintak yang perlu ditekankan pada model Problem Based Learning. Adapun sintaks yang telah dilakukan Guru dalam implementasi model Problem Based Learning adalah sebagai berikut:

Tabel 1 Sintak Model Problem Based Learning

\begin{tabular}{|l|l|}
\hline Fase & Perilaku Guru \\
\hline Fase 1 & Guru membahas tujuan \\
Memberikan orientasi tentang & pembelajaran, mendeskripsikan \\
permasalahan kepada siswa & berbagai kebutuhan logistik penting, \\
\hline
\end{tabular}

${ }^{9}$ Trianto, Mendesain Model Pembelajaran Inovatif-Progresif, Surabaya: Kencana Prenada Media Group, 2007, hlm 70. 


\begin{tabular}{|c|c|}
\hline & $\begin{array}{l}\text { dan memotivasi siswa untuk terlibat } \\
\text { dalam kegiatan mengatasi masalah. }\end{array}$ \\
\hline $\begin{array}{l}\text { Fase } 2 \\
\text { Mengorganisasikan siswa }\end{array}$ & $\begin{array}{l}\text { Guru membagi siswa ke dalam } \\
\text { kelompok, membantu siswa untuk } \\
\text { mendefinisikan dan } \\
\text { mengorganisasikan tugas-tugas } \\
\text { belajar yang terkait dengan } \\
\text { permasalahannya }\end{array}$ \\
\hline $\begin{array}{l}\text { Fase } 3 \\
\text { Membantu investigasi mandiri dan } \\
\text { kelompok }\end{array}$ & $\begin{array}{l}\text { Guru mendorong siswa untuk } \\
\text { mendapatkan informasi yang tepat, } \\
\text { melaksanakan eksperimen dan } \\
\text { mencari penjelasan dan solusi } \\
\text { permasalahan yang diajukan }\end{array}$ \\
\hline $\begin{array}{l}\text { Fase } 4 \\
\text { Mengembangkan dan menyajikan } \\
\text { hasil }\end{array}$ & $\begin{array}{l}\text { Guru membantu siswa dalam } \\
\text { merencanakan dan } \\
\text { menyiapkan laporan, dokumentasi, } \\
\text { atau model, dan } \\
\text { membantu mereka berbagi tugas } \\
\text { dengan sesama }\end{array}$ \\
\hline $\begin{array}{l}\text { Fase } 5 \\
\text { Menganalisis dan mengevaluasi } \\
\text { proses mengatasi masalah. }\end{array}$ & $\begin{array}{l}\text { Guru membantu siswa untuk } \\
\text { melakukan refleksi atau } \\
\text { evaluasi terhadap proses dan hasil } \\
\text { penyelidikan yang } \\
\text { mereka lakukan. }\end{array}$ \\
\hline
\end{tabular}

Pada fase 1 sesuai dengan fase awal model Problem Based Learning yakni dilakukan guru dengan mengkomunikasikan dengan jelas maksud pelajarannya, membangun sikap positif terhadap pelajaran itu, dan mendeskripsikan sesuatu yang diharapkan untuk dilakukan oleh siswa. Pada fase ini, guru memberikan 
gambaran yang berkaitan dengan materi shalat jum'at secara jelas kepada seluruh siswa. Pada fase $1 \mathrm{ini}$, guru menyodorkan situasi bermasalah dengan hati-hati atau memiliki prosedur yang jelas untuk melibatkan siswa dalam identifikasi permasalahan berkaitan dengan materi shalat jum'at. Adapun permasalahan yang diajukan guru berkaitan dengan pelaksanaan shalat Jum'at di berbagai situasi dan kondisi yang berkembang di masyarakat, terutama untuk masyarakat yang sedang bepergian. Siswa diminta untuk menyelesaikan permasalahan hukum Islam penyelenggaraan shalat Jum'at ketika seseorang bepergian dengan menggunakan Kapal laut. Siswa diminta untuk memberikan gambaran tentang hukum Islam pelaksanaan shalat Jum'at baik tata cara, jumlah orang yang ikut dalam shalat Jum'at dan hal-hal lain yang berkaitan dengan shalat Jum'at.

Permasalahan terkait pelaksanaan shalat Jum'at juga diberikan guru dengan memberikan gambaran atau komparasi lain pada situasi dan kondisi lain yang perlu dipahami siswa. Guru membuat permasalahan ke dalam sebuah narasi cerita yang menarik dan menggugah siswa untuk berfikir secara kritis.

Fase 2 dilakukan dengan membagi siswa dalam lima kelompok, di mana masing-masing kelompok berjumlah 5 siswa. Kelompok dipilih berdasarkan heterogenitas siswa baik dari jenis kelamin maupun tingkat kepandaian siswa. Hal tersebut agar siswa dapat saling bekerjasama terutama bagi siswa yang lebih pintar dapat membantu temannya yang memiliki pemahaman yang kurang. Pada fase ini guru membantu siswa untuk mendefinisikan dan mengorganisasikan tugas-tugas belajar yang terkait dengan permasalahan yang telah diberikan pada fase sebelumnya agar siswa mampu memahami permasalahan yang perlu dipecahkan.

Fase 3 ditekankan untuk membantu investigasi mandiri dan kelompok. Investigasi yang dilakukan secara mandiri, berpasangan, atau dalam tim-tim studi kecil adalah inti dari Problem Based Learning. Meskipun setiap situasi masalah membutuhkan teknik investigasi yang agak berbeda, kebanyakan melibatkan proses mengumpulkan data dan eksperimentasi, pembuatan hipotesis dan 
penjelasan, dan memberikan solusi. Semakin banyak permasalahan yang dapat dipecahkan siswa maka akan banyak data yang dapat dikumpulkan siswa dengan cara eksperimen maupun studi pustaka yang akan dapat memperkaya pengalaman dan pemahaman siswa. Dengan demikian siswa dapat memberikan analisis dan memberikan jawaban terhadap permasalahan yang diberikan guru maupun dapat memberikan solusi yang tepat bagi permasalahan yang diberikan oleh guru.

Fase ke 4 dilakukan dengan mengembangkan dan menyajikan hasil. Fase ini dilalui siswa dengan mengembangkan situasi dan kondisi yang mungkin dialami dalam pelaksanaan shalat Jum'at. Pada fase ini siswa diharapkan mampu menyajikan solusi terkait permasalahan tata cara pelaksanaan shalat Jum'at ketika dalam perjalanan menggunakan alat transportasi kapal laut. Solusi tersebut juga diharapkan dapat diberikan dalam situasi dan kondisi lain misalnya dalam perjalanan dengan kapal udara, kereta api maupun alat transportasi lain. Adapun solusi yang diberikan siswa dalam mengatasi permasalahan adalah sebagai berikut: penentuan kiblat ditentukan berdasarkan arah kompas, bila dalam perjalanan tersebut tidak memenuhi syarat 40 orang, maka ditentukan berdasarkan hukum dari madzhab Maliki terutama harus ada imam, makmum, dan terdapat khotbah yang menjadi syarat utama sahnya shalat Jum'at.

Fase 5. Menganalisis dan mengevaluasi proses mengatasi masalah. Fase terakhir Problem Based Learning melibatkan kegiatan-kegiatan yang dimaksudkan untuk membantu siswa menganalisis dan mengevaluasi proses berpikirnya sendiri maupun keterampilan investigatif dan keterampilan intelektual yang mereka gunakan. Melewati fase pertama hingga fase terakhir diharapkan siswa dapat mengkontruksi pemahaman tentang fiqh dalam pelaksanaan shalat Jum'at. Hal terpenting adalah memahami bahwa agama Islam memberikan keringanan bagi seseorang yang bepergian, tetapi tetap berpedoman pada aturan agama. Pada fase ini, guru memberikan evaluasi terhadap solusi yang diberikan oleh siswa dalam mengatasi permasalahan yang telah diberikan pada fase sebelumnya. Guru harus dapat memberikan pemahaman yang menyeluruh bagi 
siswa agar dapat digunakan sebagai pedoman atau dasar dalam kehidupan seharihari.

Implementasi Problem Based Learning dilakukan guru dari mulai perencanaan, pelaksanaan dan evaluasi. Perencanaan yang dilakukan guru dilaksanakan dengan menyesuaikan materi dan perangkat pembelajaran yang diperlukan dalam memahami materi shalat jum'at dan masalah yang berkaitan dengan shalat Jum'at. Perangkat pembelajaran dipersiapkan guru sebelum mengajarkan materi. Pada tahap perencanaan ini, guru juga membuat pemetaan yang berkaitan dengan permasalahan yang akan dikaji dalam pembelajaran terutama berkaitan dengan perkembangan hukum Islam dengan kondisi masyarakat dalam menjalankan ibadah shalat Jum'at.

Pelaksanaan model Problem Based Learning dilaksanakan dengan memperhatikan sintak pada model pembelajaran ini, yakni guru membuat pemetaan kegiataan dari fase 1 hingga fase ke 5 dari model pembelajaran ini. Pada pelaksanaan model Problem Based Learning dapat dilihat antusiasme siswa dalam menyelesaikan permasalahan yang diberikan oleh guru terkait masalah yang diajukan oleh guru. Sintak pada model pembelajaran ini tiap fasenya juga dapat terselesaikan dengan baik dan sesuai tahapan yang semestinya dalam penerapan model pembelajaran ini.

Pada tahap evaluasi, dapat dilihat bahwa siswa telah mampu memberikan solusi terkait permasalahan yang telah diajukan oleh guru. Berdasarkan hasil evaluasi dapat dilihat bahwa hasil belajar siswa 80\% telah mencapai KKM dan aktivitas siswa dapat terlihat lebih aktif dan tertarik dalam pembelajaran Fiqh. Dengan demikian penggunaan model Problem Based Learning dapat digunakan sebagai salah satu alternatif model pembelajaran yang dapat digunakan dalam mata pembelajaran Fiqh terutama dalam materi shalat Jum'at. 


\section{SIMPULAN}

Penerapan model Problem Based Learning pada mata pelajaran fiqh disesuaikan dengan sintak model tersebut. Implementasi model Implementasi Problem Based Learning dilakukan guru dari mulai perencanaan, pelaksanaan dan evaluasi. Perencanaan yang dilakukan guru dilaksanakan dengan menyesuaikan materi dan perangkat pembelajaran yang diperlukan dalam memahami materi shalat jum'at dan masalah yang berkaitan dengan shalat jum'at. Pelaksanaan model Problem Based Learning dilaksanakan melalui 5 fase yang setiap fasenya disesuaikan dengan langkah-langkah yang harus dilaksanakan oleh guru dan siswa. Fase pertama dilakukan dengan memberikan orientasi tentang permasalahan kepada siswa, fase kedua dilakukan dengan mengorganisasikan siswa. Fase ketiga dilakukan dengan membantu investigasi mandiri dan kelompok. Fase selanjutnya dilakukan dengan mengembangkan dan menyajikan hasil dan fase yang terakhir dilakukan dengan menganalisis dan mengevaluasi proses mengatasi masalah. Fase-fase tersebut merupakan langkah-langkah yang perlu diperhatikan guru dalam mengimplementasikan model Problem Based Learning dan setiap fase harus dapat memberikan pemahaman yang bermakna bagi siswa dalam memahami pembelajaran.

Pada pelaksanaan model Problem Based Learning dapat dilihat antusiasme siswa dalam menyelesaikan permasalahan yang diberikan oleh guru terkait masalah yang diajukan oleh guru yakni permasalahan dalam pembelajaran fiqh, yakni pada pelaksanaan shalat Jum'at ketika bepergian. Sintak pada model pembelajaran ini tiap fasenya juga dapat terselesaikan dengan baik dan sesuai tahapan yang semestinya dalam penerapan model pembelajaran ini. Peran guru sangat besar dalam menentukan pemahaman siswa pada tiap fase, yakni dari fase pertama hingga fase kelima. Keberhasilan implementasi model Problem Based Learning pada mata pelajaran fiqh dapat dilihat dari pemahaman siswa terkait permasalahan fiqh yang diberikan oleh guru. Adapun pemahaman siswa dalam

pembelajaran fiqh dapat dilihat dari hasil belajar baik secara kognitif, afektif 
maupun psikomotorik. Keberhasilan pembelajaran juga dapat dilihat dari kegiatan aktif siswa dalam implementasi model Problem Based Learning pada mata pelajaran fiqh. 


\section{DAFTAR PUSTAKA}

Abbudin, Nata, Perspektif Islam tentang Strategi Pembelajaran, Jakarta: Kencana, 2011.

Arends, Richard I, Learning to Teach: Belajar untuk Mengajar, Yogyakarta: Pustaka Pelajar, 2007.

Keputusan Menteri Agama No 165 Tahun 2014, Pedoman Kurikulum madrasah 2013 Mata Pelajaran Pendidikan Agama Islam dan Bahasa Arab, Jakarta: Depag.

Moleong, J Lexy, Metode Penelitian Kualitatif, Bandung: Remaja Rosdakarya, 2005.

Ngalimun, Strategi dan Model pembelajaran, Yogyakarta: Aswaja Presindo, 2013.

Rusman, Model-Model Pembelajaran, Bandung: Rajawali Pers, 2010.

Sanjaya, Wina, Strategi Pembelajaran Berorientasi Standar Proses Pendidikan. Jakarta: Prenada Media Group, 2010.

Shoimin, Aris, Model Pembelajaran Inovatif dalam Kurikulum 2013, Yokyakarta: ARruz media, 2014.

Trianto, Mendesain Model Pembelajaran Inovatif-Progresif, Surabaya: Kencana Prenada Media Group, 2007. 